\title{
Hak dan Kewajiban Remaja Dalam Kesehatan Psikologi
}

Salva ayu vidias putri

Institut Ilmu Kesehatan Strada Indonesia

Salvaayuvp12@gmail.com

\begin{abstract}
Abstrak
Dunia remaja adalah dunia yang penuh warna dan unik. Dari sekian untaian pertumbuhan dan perkembangan remaja, masa yang paling sering menjadi perhatian tentu saja adalah ketika masa pubertas itu datang. Jenjang pertumbuhan secara jasmani tersebut dapat dipakai sebagai ciri pertumbuhan remaja di tingkat awal yang selanjutnya akan dilanjutkan dengan masa ketika remaja mengalami fase penyesuaian diri antar-pribadi dan lingkungan sosial yang lebih luas. Sejak itulah muncul berbagai kelompok remaja yang disebut dalam berbagai istilah. Di dalam artikel ini, terdapat uraian seputar perkembangan psikologi remaja, peranan orang tua terhadap psikologi anak, dan pengaruh lingkungan terhadap perkembangan psikologi anak, serta kewajiban remaja dalam kesehatan psikologinya. Kesimpulannya anak dan remaja adalah generasi penerus, mereka menjadi bakal atau calon yang penting. yang akan menggantikan tugas-tugas para seniornya, yakni meneruskan membangun bangsa dan negara. Tanpa mereka maka negara bukan apa-apa, maka setidaknya kita bisa memahami psikologi, sikap dan kemauankemauan mereka sehingga akan tercipta hubungan yang harmonis yang bisa menjadikan remaja menjadi generasi yang aktif dan produktif.
\end{abstract}

\subsection{Latar Belakang}

Dalam perkembangan kepribadian seseorang, masa remaja memiliki arti yang khusus, namun begitu masa remaja mempunyai tempat yang tidak jelas dalam rangkaian proses perkembangan seseorang. Hal itu dikarenakan remaja tidak termasuk golongan anak, tetapi ia tidak pula termasuk golongan orang dewasa. Seorang anak masih belum selesai perkembangannya, orang dewasa dapat dianggap sudah berkembang penuh. Sedangkan Remaja walaupun sudah mulai berkembang namun belum mampu untuk menguasai fungsi fisik psikisnya dengan baik.

Remaja berada dalam status interim sebagai akibat dari pada posisi yang diberikan oleh orang tua dan sebagian diperoleh dari usaha mereka sendiri yang selanjutnya memberikan prestise tertentu padanya. Status ini berhubungan dengan masa peralihan yang timbul sesudah pemasakan seksual (pubertas). Masa peralihan tersebut diperlukan untuk mempelajari remaja mampu memikul tanggung jawabnya nanti dalam masa dewasa. Oleh sebab itu suatu pendidikan yang emansipatoris akan membantu remaja untuk melepaskan status interimnya supaya ia dapat menjadi dewasa yang bertanggung jawab.

Fase-fase Masa Remaja Suatu analisa yang cermat mengenai semua aspek perkembangan dalam remaja, secara global masa remaja berlangsung antara umur 1221 tahun, dengan pembagian 12-15 tahun :masa remaja awal, 15-18 tahun masa remaja pertengahan, 18-21 tahun : masa remaja akhir.

Dalam buku-buku Jerman masih ada pembagian yang lain lagi yaitu pembagian dalam prapubertas (masa peralihan dari masa anak-anak ke masa remaja), pubertas (masa pemasakan seksual), dan adolesensi 
(masa remaja akhir sebelum memasuki masa dewasa).

Pra pubertas adalah periode sekitar 2 tahun sebelum terjadinya pemasakan seksual yang sesungguhnya tetapi sudah terjadi perkembangan fisiologis yang berhubungan dengan pemasakan beberapa kelenjar endoktrin. Kelenjar endoktrin adalah kelenjar yang bermuara secara langsung di dalam saluran darah. Zat-zat yang dikeluarkan disebut hormon. Hormon-hormon tadi memberikan stimulasi pada badan anak sedemikian rupa, hingga anak merasakan rangsangrangsang tertentu, suatu rangsang hormonal yang menyebabkan suatu rasa tidak tenang dalam diri anak suatu rasa yang belum pernah dialami sebelumnya, yang tidak dimengertinya dan yang mengakhiri tahuntahun anak yang menyenangkan.

Masa pubertas atau masa pemasakan seksual umumnya terjadi ntara usia 12-16 tahun pada remaja laki-laki dan 11-15 tahun pada remaja wanita. Pubertas awal pada remaja wanita ditandai dengan menstruasi, sedangkan remaja laki-laki ditandai dengan

\subsection{Tinjauan Pustaka}

Peranan Orang Tua Terhadap Remaja Orang tua adalah orang yang paling dekat hubungan kekerabatan dengan remaja. Tetapi banyak ditemukan fakta dilapangan bahwa antara orang tua dan remaja sering kali berbeda pandanagan, seringkali mereka lebih memenitingkan teman bermain daripada kepentingan ornag atua atau keluarganya. Hal ini dikarenakan kurangnya komunikasi dari hati ke hatiantara remaja dengan orang tuanya.

Abu ahmadi dan Munawar Sholeh (1991:98-990) mengatakan bahwa, sebagai orang tua hendaknya kita berusaha, agar apa yang merupakan kewajiban anak-anak dan tuntutan kita sebagai orang tua mereka kenal dan laksanakan, sesuai dengan masa mimpi pertama yang tanpa disadarinya mengeluarkan sperma. Biasanya perkembangan biologis gadis lebih cepat satu tahun dibandingkan perkembangan biologis seorang pemuda.

Masa adolesen sebagai masa remaja akhir atau batas dewasa awal umumnya antara usia 18-21 tahun. Walaupun masih banyak ditemukan seorang anak yang berusia lebih dari 21 tahun tetapi masih dalam pengawasan orang tuanya dan belum bisa hidup mandiri secara ekonomi. Dalam kasus di atas paling tidak remaja yang sudah diambang masa dewasa sudah mengerti norma-norma masyarakat tanpa harus didikte, sudah memikirkan rencana kehidupan selanjutnya dan sudah berfikir secara bijaksana.

\subsection{Kasus Masalah}

1. Apa hak yang didapat remaja dalam peranan orang tua?

2. Bagaimana peranan lingkungan sosial dalam kesehatan psikologi remaja?

3. Apa kewajiban remaja dalam menjaga kesehatan psikologi?

kemampuan mereka dan kemampuan kita sebagai orang tua. Jika hal ini dapat kita kerjakan, maka konflik dan frustasi pada kedua belah pihak dapat dihindarkan atau paling sedikit diselesaikan.

Peranan orang tua dapat diterapkan pada hal-hal berikut ini:

a. Children learn what they live

b. Prestasi belajar.

c. Kegemaran membaca.

d. Makan bersama

e. Hobby

f. Mereka bukan lagi anak-anak.

g. Pendidikan seks.

h. Pendidikan agama.

i. Sikap positif. 


\section{Perkembangan Psikososial}

Perkembangan psikososial pada remaja menurut Erikson adalah identitas dan kebingungan peran yang terjadi pada usia 12-20 tahun. Pembentukan identitas selama masa remaja merupakan tugas utama dalam perkembangan kepribadian yang diharapkan tercapai pada masa remaja akhir.Selama masa remaja ini kesadaran akan identitas menjadi lebih kuat karena itu ia berusaha mencari identitas dan mendefinisikan kembali "siapakah"ia saat ini dan akan menjadi "siapakah" atau menjadi "apakah" ia dimasa mendatang.Perkembangan identitas selama masa remaja ini juga sangat penting karena ia memberikan suatu landasan bagi perkembangan psikososial dan relasi interpersonalpada masa dewasa.

Tahap perkembangan identitas (Desmita, 2005) meliputi: 1) tahap diferensiasi (12-14 tahun ) karakteristik tahap ini adalah remaja menyadari bahawa ia berbeda secara psikologis dari orang tuanya.Kesadaran ini sering membuatnya mempertanyakan dan menolak nilai- nilai dan nasehat orang tuanya, sekalipun nilai dan nasehat tersebut masuk akal; 2) tahap praktis (14 - 15 tahun) arakteristik tahap ini adalah remaja percaya bahwa ia mengetahui segala-galanya dan dapat melakukan sesuatu tanpa salah. Ia menyangkal kebutuhan akan peringatan atau nasehat dan menantang orangtuanya pada setiap kesempatan. Komitmennya terhadap teman-teman juga bertambah; 3) tahap penyesuaian (15-18 tahun). Karakteristik tahap ini adalah karena kesedihan dan kekhawatiran yang dialaminya mendorong remaja untuk menerima kembali sebagian otoritas orang tuanya tetapi dengan syarat. Tingkah lakunya sering silih berganti antara eksperimentasi dan penyesuaian, kadang mereka menantang dan kadang berdamai dan bekerjasama dengan orang tua mereka. Disatu sisi ia menerima tanggung jawab di sekitar rumah namun disisi lain ia akan mendongkol ketika orang tuanya selalu mengontrol, membatasi gerak gerik dan aktifitasnya diluar rumah.; 4) tahap konsolidasi (18-21 tahun). Karakteristik pada tahap ini adalah remaja mengembangkan kesadaran akan identitas personal yang menjadi dasar pemahaman dirinya dan orang lainserta untuk mempertahankan otonomi, independen dan invidualitas.

Selama masa ini remaja mulai memiliki suatu perasaan tentang identitasnya sendiri, suatu perasaan bahwa dia adalah manusia yang unik dengan sifatsifat yang melekat pada dirinya, seperti kesukaan dan ketidaksukaan, tujuan yang ingin dicapai pada masa mendatang, kekuatan dan hasrat untuk mengontrol kehidupannya sendiri.ini merupakan saat yang sulit bagi remaja karena masa peralihan dari masa kanak-kanak ke masa dewasa di satu pihak dan kepekaaan terhadap perubahan sosiial dan historis dipihak lain sehingga seorang remaja merasakan penderitaan paling dalamdibandingkan dengan masa-masa lain akibat kekacauan peranan atau kekacauan identitas (identity confusion). Kondisi ini menyebabkan remaja merasa terisolasi, hampa, cemas, dan bimbang. Remaja juga menjadi mudah tersinggung dan merasa malu.Selama masa ini tingkah laku remaja tidak konsisten dan tidak dapat diprediksi kadang tertutup terhadap siapapun karena takut ditolak atau dikecewakan namun pada saat lain mungkin ingin jadi pengikut atau pecinta dengan tidak memperdulikan konsekwensi - konsekwensi dari komitmennya (Davdson G C, 2006).

Remaja yang berhasil mencapai suatu identitas diri yang stabil akan memperoleh suatu pandangan yang jelas 
tentang dirinya, memahami perbedaan dan persamaannya dengan orang lain, menyadari kelebihan dan kekurangan dirinya, penuh percaya diri, tanggap terhadap berbagai situasi, mampu mengambil keputusan penting, mampu mengantisipasi tantangan masa depan serta mengenal perannya dimasyarakat (Desmita, 2005)

Perkembangan Psikososial Remaja Awal ( 10 - 14 Tahun ) Perkembangan psikososial remaja awal diantaranya:

a) cemas terhadap penampilan badan / fisik

b) perubahan hormonal

c) menyatakan kebebasan dan merasa sebagai seorang individu, tidak hanya sebagai anggota keluarga

d) perilaku memberontak dan melawan

e) kawan menjadi lebih penting

f) perasaan memiliki terhadap teman sebaya, anak laki-laki membentuk gang, kelompok, anak perempuan mempunyai sahabat

g) sangat menuntut keadilan tapi cenderung melihat sesuatu sebagai hitam putih serta dari sisi pandang mereka sendiri.

Dampak terhadap anak diantaranya:

a) kesadaran diri meningkat (self consciousness )

b) menjadi pemarah, anak laki-laki yang tadinya baik dapat menjadi agresif

c) bereksperimen dengan cara berpakaian, berbicara dan cara penampilan diri sebagai suatu usaha untuk mendapatkan identitas baru d) kasar dan menuntut memperoleh kebebasan

e) ingin tampak sama dengan teman dalam cara berpakaian, gaya rambut, mendengarkan musik

f) pengaruh teman menjadi sangat besar, remaja tidak mau berbeda dengan dari teman sebaya

g) tampak tidak toleransi dan sulit berkompromi, timbul iri hati dengan saudara kandung.

\section{Kewajiban remaja dalam kesehatan psikologi}

Pembelajaran shalat yang dikaitkan dengan pendidikan psihis adalah sebagai berikut :

1. Mendidik manusia agar taat kepada pimpinan yang memberi komando, karena setelah mendengar adzan dikumandangkan, kita disunnahkan bersegera menuju masjid untuk menunaikan shalat berjamaah.

2. Mendidik manusia agar memiliki kedislipinan yang tinggi dalam melaksanakan tugas yang dipikulkan kepadanya, karena shalat telah diaturkan waktunya secara jelas.

3. Mendidik manusia untuk memiliki sikap optimis dalam menyongsong masa depan, karena inti ibadah itu adalah do'a, yaitu harapan atau permohonan kepada Allah SWT yang mengatur segalagalanya.

4. Menentramkan jiwa, karena dengan shalat seseorang akan merasa senantiasa dekat dengan Allah SWT. Hal ini dapat dipahami karena dengan shalat berarti berdzikir, sedangkan berdzikir kepada Allah akan membuahkan ketentraman hati. Sebagaimana firman Allah SWT: "Ketahuilah hanya dengan berdzikir kepada Allah SWT hati akan tentram".(Q.S.Ar Ro'du : 28). 
5. Mendorong manusia berani menghadapi problematika kehidupan dengan hati sabar dan tabah. Semua problematika kehidupan dihadapi dan disadarinya sebagai ujian dari Allah SWT yang perlu diterima untuk menguji mentalnya, serta iman dan takwanya.

6. Mendidik manusia agar bersikap sportif dan gentleman untuk mengakui kesalahan dan dosanya, karena dengan shalat merupakan kesempatan yang sangat baik untuk memohon ampunan kepada Allah SWT atas segala kesalahan dan dosa-dosanya yang telah dilakukan.

7. Menghindarkan manusia dari berbuat keji dan munkar (jahat). Jika shalat dilakukan dengan sepenuh hati, dengan sikap tunduk dan tawadlu' (rendah hati) serta hati yang patuh, maka akan mendorong pelakunya untuk membentengi dirinya dari perbuatan buruk dan jahat. Firman Allah SWT. :"Sesungguhnya shalat itu dapat mencegah diri dari perbuatan keji (buruk) dan munkar (jahat)"(Q.S. Ankabut : 45)

\subsection{Pembahasan}

Masa remaja termasuk masa yang sangat menentukan karena pada masa ini anak-anak mengalami banyak perubahan pada psikis dan fisiknya. Terjadinya perubahan kejiwaan menimbulkan kebingungan dikalangan remaja, mereka mengalami penuh gejolak emosi dan tekanan jiwa sehingga menyimpang dari aturan dan norma-norma sosial yang berlaku dikalangan masyrakat. Dalam proses perkembangan kematangan psikologis dan biologis, remaja kerap menghadapi ketegangan, kebingungan, dan kekhawatiran. Remaja menjadi gemar coba-coba dalam emosi labil sehingga mudah terpengaruh.
Peranan Orang Tua Terhadap Remaja Orang tua adalah orang yang paling dekat hubungan kekerabatan dengan remaja. Tetapi banyak ditemukan fakta dilapangan bahwa antara orang tua dan remaja sering kali berbeda pandanagan, seringkali mereka lebih memenitingkan teman bermain daripada kepentingan ornag atua atau keluarganya. Hal ini dikarenakan kurangnya komunikasi dari hati ke hatiantara remaja dengan orang tuanya.

Peranan orang tua dapat diterapkan pada hal-hal berikut ini:

a. Children learn what they live

b. Prestasi belajar.

c. Kegemaran membaca.

d. Makan bersama

e. Hobby

f. Mereka bukan lagi anak-anak.

g. Pendidikan seks.

h. Pendidikan agama.

i. Sikap positif.

Perkembangan psikososial pada remaja menurut Erikson adalah identitas dan kebingungan peran yang terjadi pada usia 12-20 tahun. Pembentukan identitas selama masa remaja merupakan tugas utama dalam perkembangan kepribadian yang diharapkan tercapai pada masa remaja akhir.Selama masa remaja ini kesadaran akan identitas menjadi lebih kuat karena itu ia berusaha mencari identitas dan mendefinisikan kembali "siapakah"ia saat ini dan akan menjadi "siapakah" atau menjadi "apakah" ia dimasa mendatang.Perkembangan identitas selama masa remaja ini juga sangat penting karena ia memberikan suatu landasan bagi perkembangan psikososial dan relasi interpersonalpada masa dewasa.

Pendekatan kejiwan keagaman, adalah salah satu kewajiban remaja guna mendapatkan wawasan atau tinjauan dari 
unsur agama, dengan begitu remaja bisa menjadi remaja yang positif dan dapat menjadi remaja yang baik guna penerusan bangsa

\subsection{Kesimpulan}

Peranan Orang Tua Terhadap Remaja Orang tua adalah orang yang paling dekat hubungan kekerabatan dengan remaja. Tetapi banyak ditemukan fakta dilapangan bahwa antara orang tua dan remaja sering kali berbeda pandangan, seringkali mereka lebih mementingkan teman bermain daripada kepentingan orang tua atau keluarganya. Hal ini dikarenakan kurangnya komunikasi dari hati ke hati antara remaja dengan orang tuanya. Perkembangan Psikososial Perkembangan psikososial pada remaja menurut Erikson adalah identitas dan kebingungan peran yang terjadi pada usia 12-20 tahun. Pembentukan identitas selama masa remaja merupakan tugas utama dalam perkembangan kepribadian yang diharapkan tercapai pada masa remaja akhir. Selama masa remaja ini kesadaran akan identitas menjadi lebih kuat karena itu ia berusaha mencari identitas dan mendefinisikan kembali ia dimasa mendatang.

Perkembangan identitas selama masa remaja ini juga sangat penting karena ia memberikan suatu landasan bagi perkembangan psikososial dan relasi interpersonal pada masa dewasa.

Tahap perkembangan identitas tahap diferensiasi tahap praktis tahap penyesuaian tahap konsolidasi

Pembelajaran shalat yang dikaitkan dengan pendidikan psikis adalah sebagai berikut

a. manusia agar taat kepada pimpinan yang memberi komando, karena setelah mendengar adzan dikumandangkan, kita disunnahkan bersegera menuju masjid untuk menunaikan

b. shalat berjamaah.

c. manusia agar memiliki kedislipinan yang tinggi dalam melaksanakan tugas yang dipikulkan kepadanya, karena shalat telah diaturkan waktunya secara jelas.

d. manusia untuk memiliki sikap optimis dalam menyongsong masa depan, karena inti ibadah itu adalah do'a, yaitu harapan atau permohonan kepada Allah SWT yang mengatur segalagalanya. jiwa, karena dengan shalat seseorang akan merasa senantiasa dekat dengan Allah SWT.

Hal ini dapat dipahami karena dengan shalat berarti berdzikir, sedangkan berdzikir kepada Allah akan membuahkan ketentraman hati. 


\section{Daftar Pustaka}

Ahmadi, Abu dan Munawar Sholeh, Psikologi Perkembangan, (Jakarta: Rineka Cipta, 1991)

Drs.Syihabuddin, Penerbit Gema Insani , Jakarta, 1999 Al-Faqih Abu Laits As-Samarqandi, Tanbihul Ghafilin, Nasehat Bagi yang lalai,

M. P Knoers, F. J Monks dan Siti Rahayu Haditomo, Psikologi Perkembangan, (Yogyakarta: Gajah Mada University Press, 1982)

Syambu, Yusuf. Psikologi Perkembangan Anak dan Remaja, (Bandung: Remaja Rosdakarya, 2002)

Siyoto, Sandu, and Muhammad Ali Sodik. Dasar metodologi penelitian. Literasi Media Publishing, 2015.

Sodik, Muhammad Ali, Sentot Imam Suprapto, and Dian Pangesti. "Faktor-Faktor Yang Berhubungan Dengan Pelaksanaan Pelayanan Prima Pegawai Di Rsui Orpeha Tulungagung." STRADA Jurnal Ilmiah Kesehatan 2.1 (2013): 24-32.

SODIK, Muhammad Ali; SUPRAPTO, Sentot Imam; PANGESTI, Dian. Faktor-Faktor Yang Berhubungan Dengan Pelaksanaan Pelayanan Prima Pegawai Di Rsui Orpeha Tulungagung. STRADA Jurnal Ilmiah Kesehatan, 2013, 2.1: 24-32.

Sodik, Muhammad Ali, and Simon Martin Manyanza Nzilibili. "The Role Of Health Promotion And Family Support With Attitude Of Couples Childbearing Age In Following Family Planning Program In Health." Journal of Global Research in Public Health 2.2 (2017): 82-89.

Sodik, M. A., \& Nzilibili, S. M. M. (2017). The Role Of Health Promotion And Family Support With Attitude Of Couples Childbearing Age In Following Family Planning Program In Health. Journal of Global Research in Public Health, 2(2), 82-89.

SODIK, Muhammad Ali; NZILIBILI, Simon Martin Manyanza. The Role Of Health Promotion And Family Support With Attitude Of Couples Childbearing Age In Following Family Planning Program In Health. Journal of Global Research in Public Health, 2017, 2.2: 82-89.

Sodik, Muhammad Ali. "Merokok \& Bahayanya." (2018).

Sodik, M. A. (2018). Merokok \& Bahayanya.

SODIK, Muhammad Ali. Merokok \& Bahayanya. 2018.

Sodik, Muhammad Ali. "Sikap Pencegahan Aborsi Ditinjau Dari Pengetahuan Tentang Bahaya Dan Resiko Kesehatan." Strada Jurnal Kesehatan http://publikasi. stikesstrada. ac. id/wpcontent/uploads/2015/02/9-SIKAP-SIKAPPENCEGAHAN-ABORSI. pdf (2014). 